\title{
Speaking to soldiers: historical consciousness and collective memory of the Great War amongst serving and retired soldiers of a Scottish infantry regiment
}

Fecha de recepción: 24/6/2021 Fecha de aprobación: 27/8/2021

\begin{abstract}
In the summer of 2017, a series of fifty-two confidential interviews were held with retired veteran and serving soldiers of The Black Watch, a Scottish infantry regiment, to establish whether a clearly identifiable core collective memory of the Great War existed within this regimental community at that time. Following a brief rationale for the choice of serving and retired soldiers as interviewees, an outline of working definitions of historical consciousness and collective memory is given. A description of the interviews and interviewees follows. Amongst the topics discussed in the interviews were visits to the battlefields of the Great War, the Scottish oral tradition, family involvement in the conflict, war poetry and film, inter-generational differences in perception of the war and formal remembrance. This article draws on the results of the interviews to examine interviewees perceptions of the conflict and describe the formation of historical consciousness of the war within the group. It finally concludes with an attempt to identify the core collective memory of the war within this regimental grouping at that time.
\end{abstract}

Keywords: Black Watch, Regimental identity, Great War, Memory, Oral traditions

Hablando con soldados: conciencia histórica y memoria colectiva de la Gran Guerra entre soldados en servicio y retirados de un regimiento de infantería escocés 


\section{Resumen}

En el verano de 2017, se llevaron a cabo una serie de cincuenta y dos entrevistas confidenciales con veteranos retirados y soldados en servicio del Black Watch, un regimiento de infantería escocés. Se buscaba establecer si existía una memoria colectiva central claramente identificable de la Gran Guerra dentro de esta comunidad de regimiento en ese momento. Luego de una breve explicación de la elección de soldados en servicio y retirados como entrevistados, se ofrece una descripción de las definiciones básicas de conciencia histórica y memoria colectiva. Posteriormente, se incluye una descripción de las entrevistas y los entrevistados. Entre los temas tratados en las entrevistas se encuentran las visitas a los campos de batalla de la Gran Guerra, la tradición oral escocesa, la participación familiar en el conflicto, la poesía y el cine de guerra, las diferencias intergeneracionales en la percepción de la guerra y la conmemoración formal. Este artículo recurre a los resultados de las entrevistas para examinar las percepciones de los entrevistados sobre el conflicto y describir la formación de la conciencia histórica de la guerra dentro del grupo. Finalmente, concluye con un intento de identificación del núcleo de la memoria colectiva de la guerra dentro de este grupo del regimiento en ese momento.

Palabras clave: Black Watch, Identidad de regimiento, Gran Guerra, Memoria, Tradiciones orales

\section{The regimental background}

On the 3rd May 2014, the monument to the men of The Black Watch who fell in the Great War and in the fight at Black Watch Corner on the 11th November 1914 was unveiled at Polygon Wood in Flanders. ${ }^{1}$ That day, retired soldiers of the old Black Watch (Royal Highland Regiment) and serving soldiers of the successor unit, The Black Watch, 3rd Battalion, The Royal Regiment of Scotland -hereafter known as 3 SCOTS- formed up behind Belgian and Scottish pipe bands and marched to the monument. ${ }^{2}$ There they joined major Belgian and Scottish political figures, Scottish civic dignitaries, Black Watch families, and friends of the regiment for the drumhead service and unveiling of the monument. $^{3}$

1 The fight at Black Watch Corner took place on 11 November, 1914 when the outnumbered and exhausted remnants of the British 1st Guards Brigade including 1st Black Watch held, turned and drove off the attacks of the Prussian Guard during the battle of Nonne Bosschen and thus secured Ypres and the British logistical operations in Channel Ports for the rest of the war. This was achieved at a terrible cost to 1st Black Watch.

2 The Royal Regiment of Scotland was formed by the merger of the old Scottish infantry regiments including The Black Watch. Young soldiers now join The Black Watch, 3rd Battalion, The Royal Regiment of Scotland, also known as 3 SCOTS.

3 A drumhead service is a church service of any denomination held in the open as on active service. 
As was the case with any unveiling of a monument on the old battlefields of the First World War, this was a major event in the history of the regiment involved and was given large scale press and television coverage in both Scotland and Belgium. Most of those present had a personal connection with the event too, for the majority of the Black Watch participants that day were related to The Black Watch men of 1914-18, and a few were the descendants of men who had taken part in the fight at Black Watch Corner. For many of those present, the ceremony also fulfilled the larger function of marking the actual start of the public centenary commemorations of the Great War, which continued throughout Britain until 11th November 2018 and beyond.

\section{Introduction}

It was against this background of ongoing commemoration that in the summer of 2017, a series of fifty-two interviews with retired and serving soldiers of The Black Watch and 3 SCOTS were held to explore three issues. First, how did the serving soldiers and retired veterans of today perceive the Great War, and second, what evidence was there of individual historical consciousness of the war amongst them. Finally, after the results of the interviews had been assembled and analysed, material gathered from that process would be used in an attempt to identify and describe such collective memory of that conflict as existed amongst the fifty-two interviewees at the time of the interviews.

Among the reasons for this choice of interview grouping comprising veterans and serving soldiers was that theirs were voices that are seldom heard. As Black Watch and 3 SCOTS men, these are the regimental successors to the soldiers commemorated by the memorial at Black Watch Corner, and the majority were also lineal descendants of the Black Watch men of 1914-1918. These men are not academic historians or military commentators, rather in most cases the rank and file of the regiment, but as men of a military background -no matter how humble- they might bring original observations and perceptions of aspects of the war that civilians of similar background might easily miss. In addition, by interviewing this group rather than civilians, the results of this process did at least have the potential to add something new to our understanding of historical consciousness and collective memory of the Great War.

At least part of this potential to add something new is because the veterans and serving soldiers interviewed in this project were all both heirs to and participants in a regimental tradition peculiar to the British army, where British, and some claim particularly Scottish infantry military identity, is based on the regiment and not on the army or even infantry as a whole. In this tradition, men can expect to remain with one regiment for their whole service, where it is not unknown for brothers to serve together and sons to follow their fathers into the same regiment. It is here that the young soldier discovers not only his 
place in organisation but also finds friends and, above all, learns what makes his regiment special and what is expected of him in good days and bad. In this system, the connections between local areas and individual regiments are also very strong. The old Black Watch recruited where possible from the Scottish counties of Angus, Perthshire, Fife and the City of Dundee. Today, 3 SCOTS as part of the Royal Regiment of Scotland recruits from Scotland. The exact nature of this culture has changed and developed over the years -sometimes driven by legislation such as the Childers Reforms of 1881- and is not without its detractors, but even so, it remains a powerful aspect of British military life.

\section{Working definitions}

The project drew on the work of Rüsen, Kansteiner and Heathorn, particularly in terms of definitions of historical consciousness and collective memory, which in turn informed both the questions asked and how the interviews were conducted. The concept of historical consciousness as discussed here is taken from the work of Jörn Rüsen (2012), who considers it to be a process of "historical sense-generation" further defined as the "mental procedure by which the past is interpreted (by us) for the sake of understanding the present and anticipating the future." This mental procedure, which Rüsen regards as at the very heart of all historical consciousness, played a major part in how the interview questions were framed, and particularly in the way the interviews were conducted. In order to stimulate this mental procedure identified by Rüsen, interviews were structured to include a significant number of questions intended to encourage broad reflection on what the interviewees knew about the Great War. General encouragement of the verbalisation of thoughts and feelings engendered by the interviewee's own reflections during their interviews was intended to further develop the process of Rüsen's historical sense generation.

When collective memory was considered, the definition used here was that of Kansteiner, where it was taken to mean "the shared representation of the past" $(2002,181)$. He has described this definition as the "historians preferred primary theoretical reference point", and as he also points out, collective memory is a collective phenomenon, but "it only manifests itself in the actions and statements of individuals", evidence of which is exactly what the interviews set out to record $(2002,180)$. However, as Heathorn indicated, "Great War memory has never been something singular or fixed" and, as was also noted by Kansteiner when he discussed collective memory as above, it is "always mediated" $(2005,1122)$. Similarly, in her discussion of Rüsen's work on historical consciousness, Clark makes the same point, stating it too is "ultimately fluid and shifting constantly during our lives" $(2014,189)$. In that context, it seems entirely reasonable to ask whether or not it is actually possible to identify and describe a core Black Watch collective memory of the Great War? 
In fact, this article will argue that the results of the interviews contradict that view and that a core collective memory of the Great War amongst serving and retired Black Watch soldiers can be derived from the results of the interviews.

\section{Interviews and interviewees}

Those men who were interviewed and whose thoughts are discussed here are defined by one common factor - their experiences of British military life, and at a time when the British army is shrinking, that experience is unusual in itself today. Of course, although none of the retired soldiers interviewed fought in the Great War, they, like the serving soldiers, all have had the experience of wearing a uniform and being subject to military law, earning a living by military service, obeying the commands of those appointed over them, and of life in an infantry rifle company. All retired soldiers interviewed had served "on operations" in what the Army euphemistically calls armed deployment of troops in an active service role. Except for two men, the serving soldiers had also been "on operations". All those interviewed also joined The Black Watch or 3 SCOTS with the expectation that they would see active service one day, either in a warfighting or peacekeeping role, or in aid of the civil power, or in a Cold War suddenly turned hot.

The serving soldiers interviewed were defined by their membership of 3 SCOTS and included Privates as well as Non-Commissioned, Warrant and Commissioned Officers in an approximate numerical ratio to the establishment strength of that Battalion. The serving non-commissioned soldiers were selected by their Sergeants Major at random from those men available during the three-day-long interview visit to their barracks. The three officers interviewed were selected by the Adjutant, and all were university graduates ranked as Second Lieutenant, Captain and Major. Each man had been instructed to choose a pseudonym, spoke in confidence on the guarantee of anonymity and was interviewed privately. It was also agreed that no sound recordings would be made. All knew that they were being interviewed by a former Black Watch non-commissioned soldier.

The retired soldiers -all former Black Watch men- were members of the Black Watch Association who had answered a call for volunteers from across the old Black Watch area of Angus, Dundee, Fife and Perthshire. They were all interviewed privately in their homes and are identified as, for example, Veteran $X$. Four of the interviewees had been officers, including one retired Lieutenant General and three Majors while the remainder comprised a similar mixture to the serving soldiers of non-commissioned ranks, including Warrant Officers, Sergeants and other ranks. Two of those interviewed were university graduates. Of the twenty-seven retired soldiers interviewed, twelve were still in full-time employment while the others had retired from civil employment due either to age or disablement. 
All retired and serving soldiers took part in a structured interview where everyone was questioned on the core topics in the following order: "Self and Service", "Family connections with the old regiment", "Family service in the Great War", "Possible influences on their individual perceptions of the Great War" and "Remembrance". Each of the core topics was addressed in few key factual questions, and the interviewee's opinion was requested on one or two associated issues. ${ }^{4}$ Then, as mentioned earlier, verbalisation of thoughts and feelings engendered by the interviewee's own reflections during their interviews was encouraged. Because serving soldiers and veterans are often unwilling to talk to strangers, they were told that when a topic of conversation arose they felt uncomfortable with, or a question was asked they did not want to answer, they were to say "No comment" rather than pretend not to understand. In fact, initial worries they might be uncommunicative and not engage were unfounded: both retired and serving soldiers did actively reflect on different aspects of the Great War during interviews and conversations with them contained significantly higher levels than expected of what Rüsen described as "historical sense generation".

\section{Identifying examples of individual historical consciousness}

In a general sense, active reflection on the Great War and an accompanying rapid evolution of individual historical consciousness were particularly noticeable amongst both serving and retired soldiers who had either visited the battlefields of the Great War or had taken part in the drumhead service at Black Watch Corner or other centenary events in Scotland, France or Flanders.

The first indication of this occurred in an interview with a serving soldier, Scotty1, when he used the phrase "clicked onto it" about standing at Black Watch Corner. This phrase, often associated with battlefield target acquisition, described a flash of instant understanding - in this case of what had happened a century ago on the ground where they had been standing, and where a casual kick to the topsoil still often reveals battlefield debris in the shape of a button, empty cartridge case or shrapnel ball. Another man who felt the same flash of instant understanding was a veteran who had read his Black Watch grandfather's diary many years ago and found the entry for the day of the first engagement with the enemy in 1914: "today I shot officers and men of the German Army".

Other interviews indicated that for as many as ten of the serving soldiers, acquiring a significant degree of historical consciousness in a Great War battlefield setting had been nearly instantaneous. That sharp sense of the reality

4 One example of this was "Do you know what 'Shot at dawn' means?" An opinion would be requested and that was almost always followed by reflection on the use of the death penalty in wartime for military crimes such as desertion. (It is worth pointing out that before the interviews took place there had been some debate in Britain over this issue.) 
and an understanding of what had happened there was shared by Cal, who had related how walking the battlefields when still at school had brought an immediate sense of realism and depth to his perception of the war, further developed by subsequent visits. For others, battlefield visits were a very personal experience, but for all involved, the interview process showed that Rüsen's "historical sense generation" was in operation, and therefore, if one accepts his thinking, a growth in individual historical consciousness was also taking place.

The same can be said of interviews with the retired soldiers. Some related they had felt a sense of something best described as both deeply emotional and ancestral as they stood on the ground at Black Watch Corner and elsewhere where their ancestors had fought so hard. Here Kansteiners "historical sense generation" was about both people and events. For Veteran 5, a standard-bearer at the unveiling, that feeling verged on awe of the men involved and of what had happened that day, perhaps because his grandfather had been one of the few survivors of the fight at Black Watch Corner. This is not to say the same did not apply to some of the serving soldiers too, but because, as will be seen later, so many retired soldiers saw the war in terms of named relatives or had known the men who had fought, the personal element appeared to have been more immediate for them.

There were also occasional brief hints that Pierre Nora's work on lieux de mémoire might find an echo here, particularly the idea that the purpose of lieux is to block time and stop the process of forgetting. Nora's remark that "Memory attaches itself to sites, whereas history attaches itself to events" may go some way towards explaining why several retired soldiers described individual sites as having a deeply historic feel to them $(1989,22)$. Unfortunately, all except one were unwilling to elaborate on these feelings, but the exception, Veteran Pipe Major 1, who was of Scottish heritage, but born and brought up in New Zealand, recalled a similar experience on 25th April 2003 when, after playing the lament for the fallen and guarding the ANZAC Day Memorial Service in Iraq, he stood at the ANZAC Memorial there in private remembrance of a relative killed with the New Zealand contingent in 1916.

Interviews also showed that historical consciousness for a number of retired soldiers has also taken a practical turn, and to some extent, this marks a move away from previous acceptance by many of oral transmission of the regimental and family story as history. Inspired in part at least by the centenary commemorations, more than half of the retired soldiers have either pursued family members through the local press themselves or got a friend to do it - simply in the hope of finding an obituary or a photograph. All of the men involved volunteered the information that they intended to pass on the story and the written evidence so that for them, historical consciousness had a distinct hereditary function. ${ }^{5}$ In that context, it is interesting to note that 
Veteran Warrant Officer 2, one of the very few men to have had the mantle of a traditional seannachie virtually thrust upon him, has recently committed part of his stock of oral history to print (McCluskey, 2016). In many ways, he and his work represent what might be seen as a local interface of regimental and family story and myth with documented history, for in the role of unofficial seannachie in the presence of retired and young serving soldiers, he tells the stories of the actions and the men of the Great War at Regimental Association gatherings such as the annual El Alamein Dinner and as he did on the battlefield at Black Watch Corner in 2014.

On a practical level, almost all of the men who searched for relatives were successful.

\section{Shared and common experiences and the growth of historical consciousness}

While examples of historical consciousness given in the last section largely relate to individuals, it is also worth looking at how what Kansteiner describes as "those intellectual and cultural traditions that frame our understanding of the past" relate to common experiences shared at some point by all interviewees $(2002,180)$.

The most obvious example of this was seen when interviewing men who had visited the Western Front, for time and again, there was a distinct sense that when retired and serving soldiers described looking at the battlefields of the war, they saw these first in terms of issues such as ground, tactics, weapons capabilities, fields of fire and other purely military concerns. Conversations centred on the technology and scale of the war rather than on blame, whether of generals or politicians. In a way, it was almost as if no matter how long some men had been out of uniform, the old ways of thinking either remained or were resurrected in that company.

On another level, one particular tradition carried forward from the Black Watch by 3 SCOTS which could reasonably have been expected to have contributed to both individual historical consciousness and collective memory, is the practice of teaching regimental history. When every interviewee was asked if they had been taught regimental history, forty-two of the fifty-two men interviewed confirmed they had, and another four considered themselves mostly but not exclusively self-taught. The overwhelming majority could still name the person who taught them and could recount some of the topics covered, from the regiment's first muster at Aberfeldy in 1739 to the action at Al Basrah during the Iraq war of 2003.

Other men took the study further: Ian1, who read around the subject widely out of personal interest, was one, but whether largely self-taught or 
regimentally taught, there was no sense in which the Great War can be said to have had special treatment. The view that the Great War was only one part of a long continuum that began at the first muster at Aberfeldy was widespread, if not near universal. Other men went further: the idea that the chain of history would continue through the agency of 3 SCOTS as the successor formation -and therefore custodians of the joint past- was deliberately and clearly expressed in varying forms by eighteen of the twenty-five serving soldiers. In these circumstances, the teaching of regimental history appears to have contributed far more to the serving soldiers' individual or collective historical consciousness of the regiment's history rather than of the Great War.

Another experience common to everyone interviewed where individual historical consciousness of the conflict could have been expected to have developed at school, particularly for the serving soldiers. Unlike during the older men's schooling, serving soldiers were taught about the Great War, for by the time they went to school, the Great War was history and not the recent past. Today it is a popular topic taught up to Higher Level History in Scottish schools. However, apart from one or two exceptions, the teaching of history seems to have had little impact on the serving soldiers. M.S.R. described it as a "total non-event", and Dec1 stated very clearly that he thought the teaching was "unbalanced", hinting strongly he thought it had a distinct anti-army feel to it. All this was irrelevant to the retired soldiers simply because the war was not taught in history when they were at school.

On the other hand, the teaching of British poetry of the Great War during English lessons in the overwhelming majority Scottish secondary schools seems to have had far more impact on how the serving soldiers thought about the war. The poets whose work is studied had nothing to do with the Black Watch, but the impact of their work can be seen in as much as it was recognised immediately: Wilfred Owen's Dulce et Decorum Est (Kendall, 2013, 153) and Anthem for Doomed Youth (Kendall, 2013, 154) were immediately recognised by twelve and thirteen soldiers out of twenty-five respectively, Rupert Brooke's The Soldier (Kendall, 2013, 106) by seventeen while only four soldiers did not recognise any of these. Snatches of other poems appeared unsolicited including Sassoon's The Kiss (Kendall, 2013, 90), the best-known line of which is probably "Brother lead and sister steel". Newbolt's Vitai Lampada lines, "The voice of a schoolboy rallied the ranks, Play up! Play up! and play the game" (1921, 96-97), and even Housman's Epitaph on an Army of Mercenaries line, "they saved the sum of things for pay" (Stallworthy, 1984, 164), was dragged in to describe the fight at Black Watch Corner at one point. However, while all but three of the retired soldiers recognised Brooke's The Soldier, only three of the youngest recognised any of the other poems, perhaps because these were not taught in Scottish schools much before 1985.

When the effect war poetry had on individuals was discussed, U.N.K.'s response that he considered the poetry to have been a "major influence" on his perception of the Great War was broadly typical. On a broader level, Ian1 made the 
point that poetry might well be the major determining factor in how some men would perceive the Great War over the long term. When pressed on that point and asked to consider the possibility that while the American Civil War could be seen as the war of the still photograph, the Great War might be seen as the war of the early moving image, Ian1 was adamant that his personal perception of the conflict had been -and would continue to be- deeply influenced by war poetry. His dismissal of the idea of significant development of individual historical consciousness of the conflict being formed by contemporary film was total.

When the role of the moving picture in the formation of the men's own historical consciousness of the war was discussed, it was clear that for the majority of serving and retired soldiers, the impact of war films of any sort can only be described as limited. However, it is also worth noting that individual films clearly had been instrumental in forming attitudes for a few men. The table following was constructed from the films mentioned in the interviews. In the case of the retired soldiers, the spread of films seen and remembered was significantly wider than for the serving soldiers, and the film most widely seen by them was All Quiet on the Western Front. It also seems that, in almost every case, this was the original 1930 version, and while a number of men thought it had made a considerable emotional impression on them, they were uncomfortable about elaborating on that. Interestingly, far more retired soldiers thought that moving pictures as film clips in television documentaries had more impact over the long term on how they saw the war. Two men claimed to have deliberately chosen not to watch films about the Great War at some point they could not remember.

Table 1: Films named during interviews as seen by retired and serving soldiers as influential in how they saw the Great War

\begin{tabular}{lccc}
\hline \multicolumn{1}{c}{ Title and Year of Release } & Retired Soldiers & $\begin{array}{c}\text { Serving } \\
\text { Soldiers }\end{array}$ & Totals \\
\hline All Quiet on the Western Front (1930 \& 1979) & 10 & 6 & 16 \\
\hline Gallipoli (1981) & 3 & 3 & 6 \\
\hline On the Road to Passchendaele (2011) & 1 & 3 & 4 \\
\hline Aces High (1976) & 1 & 2 & 3 \\
\hline War Horse (2011) & 1 & 3 & 4 \\
\hline Joyeux Noel (2005) & 1 & 4 & 5 \\
\hline Blue Max (1966) & 1 & 2 & 3 \\
\hline Light Horsemen (1987) & 1 & 0 & 1 \\
\hline Guns of Loos (1928) & 1 & 0 & 1 \\
\hline Franz (2016) & 1 & 1 & 2 \\
\hline Battle of the Somme (1916) & 1 & 0 & 1 \\
\hline Unidentified films seen - all English language & 3 & 9 & 12 \\
\hline Individuals who could not recall knowingly watching & 2 & 7 & 9 \\
a Great War film & & & \\
\hline
\end{tabular}

In the case of the serving soldiers, almost a quarter, or seven out of twenty-five claimed they had not knowingly watched a film about the Great War, but as 
more than one candidly admitted, they could have mistaken the Great War for the Second World War. However, of the remainder, while only six had seen All Quiet, surprisingly, another four had watched and enjoyed Joyeux Noel (2005), which dealt with the Christmas truce from the perspective of the Scottish, German and French troops in the front line with dialogue in all three languages. This film, and to a lesser extent Franz (2016), with dialogue in French and German, seen by one retired and one serving soldier, initially had something of cult status, although Joyeux Noel is now regarded as more mainstream. The other films seen were very much as might have been expected, and the "films unidentified" category was unsurprising high.

In fact, despite expectations, the influence of war films on the formation of historical consciousness and individual perceptions of the war appears to have been limited and differed between generations.

\section{Oral tradition and generational differences in historical consciousness}

The old regimental recruiting area of Angus, Dundee, Perthshire and Fife has always had a strong oral tradition of storytelling and family narratives, and the retired soldiers were brought up when that tradition was still a significant factor in the lives of children and adolescents. To a lesser degree, that is still the case for the serving soldiers, and it is worth stating that a number of serving soldiers showed great interest in the idea of the family narrative, offering examples of the Second World War and post-war conflict family stories. In very general terms, when the role of the family story in how they thought of the war was broached, all retired soldiers always placed great importance on these - as did the serving soldiers, albeit to a lesser degree. However, when it came to both the content of these stories and how they related to how serving and retired soldiers perceived the war, there was a clear division between the older and younger retired men and another between serving and retired soldiers.

\section{Older retired soldiers}

When the discussion moved towards the content of family stories, all of the older retired soldiers invariably recounted first what they had known or seen of the survivors so that historical consciousness centred on people, not events. These older men, who tended to be around sixty years old or over, had all known Great War veterans generally as fully functioning members of society and showed a very strong tendency to see the war in terms of their experiences. Survivors were often prominent local figures of authority too: Town Councillors, teachers, doctors, shopkeepers, foremen or even workmates and sometimes, those characters who never quite recovered and who were identified with a quiet word such as "gas" or "shell shock". This level of personal knowledge was hardly surprising given that twenty-four out of all 
twenty-seven retired men interviewed had had a relative who fought, and nineteen men had a Black Watch relative in the same conflict.

At the oldest end of the interviewee age spectrum, ninety-four years old former Veteran Warrant Officer1 recalled the experience of a childhood still dominated by the war, and he was very keen to make the point that during his childhood, the Great War was not yet history. He was very firm in his conviction that while there was no discussion of the details of the war at home, the legacy of the conflict was all-pervasive. He was not alone in that opinion, for the experiences of another two men in their eighties indicated that this was akin to the formation of personal historical consciousness of the war by osmosis. There were also elements of this in the experience of others like Veteran 7, who as a child in Kirriemuir remembered seeing Victoria Cross winner 'Chae' Melvin regularly on the way to school and Veteran 9, who remembered a still traumatised Great War veteran's reaction to the outbreak of war in 1939, when that man cut a long pole and fixed his old bayonet to it "just in case" the Germans landed.

At some point in this older group, family stories generally sparked additional discussion around the possession of a family archive or Great War artefacts of some sort. Possession of some form of memento was near universal and ranged from a collection consisting of a mass of papers from enlistment to demobilisation issued to one soldier, to a few old photographs and a newspaper obituary in an envelope. Other stories appeared, but those who told them invariably stated when they had some sort of documentary evidence to support what they said. When they did not, it was made clear this was a "story".

\section{Younger retired soldiers}

Those retired men younger than sixty and over thirty formed what amounted to a transitional group between those who knew Great War soldiers and those who had no knowledge of them and between those who saw the war largely in terms of individuals and those who saw it as a whole event. Those with family stories overall tended, like the serving soldiers, to see the story and the ancestor as of equal importance. That equality between the narrative and the person may well be related to the likelihood that if they had heard any survivors speak, these were likely to have been older men like Harry Patch or other survivors who appeared on television. In a few cases, they might have seen Alfred Anderson, the last Scottish veteran who attended his last Black Watch reunion around 2002 shortly after receiving the Legion d'Honneur. But most importantly of all, it was also during their years in uniform that Halbwach's assertion, "The dead slip away into the past not because of the lengthening of the material time separating them from us but because nothing remains of the group in which they lived" could first be said to have been generally valid of Great War soldiers (Halbwachs, 1994, 167). This group also lived through a period when knowledge of the Great War went from being a part of the popular consciousness to something more akin to more specialist 
knowledge within those family groupings, which for some reason held on to the memories of the conflict. For this group, the historical consciousness of the Great War is probably best described as part of a general consciousness of the long continuum of history and less of a specific event with which they had any real contact.

\section{Serving soldiers}

The mass of serving soldiers where few were over the age of thirty was in many ways the group most difficult to define in terms of the historical consciousness of the Great War. As in the case of Leroy and Ross1, some had a detailed knowledge of their family at war, which displayed a significant degree of historical consciousness of the conflict. In their cases, a family archive containing pictures and written material existed in the care of older relatives. Scattered items such as photographs and often also pieces of Great War ephemera existed in the families of nine of the twenty-five soldiers interviewed. These men saw such items as being of at least some significance, but while others said that they had never seen anything like that, another six thought a particular elderly relative might still have something similar. Even so, in very general terms, the results of the interviews suggest very strongly that their personal linkage to the Great War, and therefore their historical consciousness as individuals, can be expressed in part in terms of their experiences on the historic battlefields of the war discussed earlier. However, an even stronger link to the conflict and one suspects the major seat of general historical consciousness of the conflict for most serving soldiers are, first, their clearly stated sense of indebtedness towards both those who had served or fallen, and second, those concrete activities associated with any sort of remembrance. In fact, not only did serving soldiers of all ranks tend to express that idea far more strongly than the retired soldiers in general, but the idea of indebtedness and remembrance appeared to have become a central plank of their historical consciousness of the war.

\section{Historical consciousness and remembrance}

In discussions with the soldiers regarding remembrance, a number of keywords appeared time and again. Foremost of those were "respect", "debt", and "repayment", so that M.S.R.'s words on formal Armistice Day parades and other commemorations sum up very neatly so many of the opinions given. "This is about the repayment of a debt", he said. Off duty time spent in preparation for formal remembrance parades was "an acknowledgement of sacrifice and a pretty poor one at that". Bloggs opinion was that "You learn very quickly that they did more than enough to deserve to be remembered". Historical distance between today and 1914 did not count: as far as Mike1 was concerned, "they came from another time and another society, but we still should remember them", while Ross 1 noted how lucky we were not to have been born at that time. 
The question of whether or not those who had served as soldiers had any sort of responsibility to encourage acts of remembrance drew a number of very clear responses of a type which indicated a high level of engagement with the question. As far as the retired soldiers were concerned, the answer was invariably a plain "yes", but the serving soldiers tended to develop their answers so that Ian1 emphasised that "as retired and serving soldiers we were all part of an organisation and in view of that we were all joint custodians of that tradition and should therefore encourage acts of remembrance". A very practical view was taken by Robbie, who agreed but added, "If you forget what had to be done, you may have to do it again". Leroy was convinced, "We who have served represent who they once were and what they once did, and that is why we have a responsibility to remember". There were dissenting voices like David1 whose answer was a firm clear "No - everyone has responsibility", but the general opinion was in agreement with $S \cot 1$ when he said "Yes - both for the boys of past and the boys of now", possibly reflecting the regimental experiences of a unit which was heavily involved in recent operations.

When the question arose as to whether there was a special obligation on the larger regimental grouping, including soldiers' families and regimental friends, to foster remembrance, opinion was more divided. Those who believed that the obligation was on the larger regimental grouping first were in the majority. This view can be found in its most developed form in Veteran Major 2 statement to the effect that while there was a clear assumption within this regimental grouping that it had a responsibility to encourage acts of remembrance, there was no moral or legal obligation on it to assume that duty. Even so, because one's real family, brothers in arms -albeit mutually self-adopted- and the larger regiment grouping overlap to such an extent, the reality is that remembrance by friends, and members of the regiment past and present assumes for many at least an equivalent status to national remembrance. There was also another view, perhaps best represented by Robbie, which acknowledged the sense of belonging within this grouping, but in terms of public acts of remembrance placed greater emphasis on maintaining a balance between the private or those of the regiment, and the public, or service-wide and national events. As he pointed out, there is often a significant difference between what something means to the regimental grouping and the nation in general. Some saw remembrance at a national level as more important than that led by the regiment and who, like Veteran Sergeant 1 see, attending the march past at the Cenotaph in London as something to be done at least once if possible. However, throughout the interviews dealing with remembrance of the Great War, one idea was near constant, particularly amongst the serving soldiers: remembrance was and remains an important aspect of belonging to the Black Watch.

In that same context of remembrance, and in view of the timings of the interviews, it is impossible to ignore the potential influence of the four years-long programmes of national commemoration. But how did the men interviewed see the centenary commemoration? The vast majority were entirely approving 
of the process, and there was a whole array of clear statements to the effect that in terms of timing, form and structure, the centenary commemorations had been entirely appropriate up to that point. Viewed dispassionately, these were always considered statements, clearly articulated and showing further evidence of what Rüsen described as "historical sense-generation". For the interviewees, the Loos remembrance parade in Dundee in 2015 and the various assemblies in different Scottish towns and cities had all struck exactly the right note. ${ }^{6}$

Even so, a very few men claimed they were indifferent to it all, a few others saw it as too "commercialised", but a larger minority were concerned simply that a sense of perspective be maintained. At their most vocal, they were concerned about devaluation by overexposure to commemoration with attendant dangers that something approaching commemoration fatigue might develop amongst the public. For one, at least, it was important that the centenary commemoration -as with all national events- be monitored in terms of potential political misuse. When the most senior retired soldier, Veteran Lieutenant General, was pressed on the same matter of political misuse, he was very clear that there had been no party political or ideological posturing of any sort during the commemorations, and that in any case that would have been entirely inappropriate. In that context, he noted that well organised, properly conducted military-led commemorative events should not be taken for triumphalism, but should be seen for what they were - well-conducted acts of public remembrance.

\section{Centenary commemoration and collective memory}

At a personal level, the overwhelming majority of retired and serving soldiers agreed when asked directly about the personal effects on them of the centenary commemorations that it had been a stimulus -albeit in some cases a rather minor prod- to look on their own involvement as something of a learning experience. But did the collective experience of centenary commemoration do more than raise historical consciousness on a large scale amongst those interviewed? Could it have been said to have contributed in some way to the collective memory of the war amongst retired and serving soldiers, and would that same consciousness endure? If, as most of the serving soldiers and many retired men thought, attendance at centenary commemoration events amounted to a learning experience of sorts, could it be that those who attend and therefore "learn" will have their perceptions of the conflict reconfigured to such an extent that it could redefine the shape of the collective memory of the regiment?

6 Every Scottish infantry regiment was involved in the Battle of Loos in 1915 and almost half of the assault troops on the first day of battle were Scots. No Scottish community escaped heavy casualties. 
That is possible, but another event much more likely to have a long-term influence on the collective memory of the regiment was the erection of the monument at Black Watch Corner, even although it is not located in the homeland. In these circumstances, it would not be surprising if that statue were to play a major role in an evolving collective memory of the Great War amongst the wider regimental community. After all, the Black Watch statue at Aberfeldy where the regiments bi-annual Aberfeldy Muster is held, erected at the first muster site in 1739 , has assumed that level of symbolic status in the wider collective memory of the Black Watch. Interestingly too, the erection and unveiling of the monument at Black Watch Corner chimes so closely with Gillis' description of how collective memories work (1994), it is difficult to ignore the possibility of such a symbolic link between the statue at Black Watch Corner and the collective memory of the Great War amongst serving and retired soldiers of the regiment. It would appear that Gillis' comments on collective memories, that "they foster and define group identities, telling a group of people where they have come from, who they are and how they should act in the present and future", also apply to the statue to some extent $(1994,7)$.

Today, reactions to the statue at Black Watch Corner on the part of the serving soldiers support that idea: "very grand", commented Ian1 while John1 saw it as "very honest", adding that, "when you look at that you know what this was all about". Lewis1 saw the statue as a necessity and not any form of luxury. His logic was straightforward: "This was a vital action, and vital actions must be marked. This is about who we are and what we are." When pressed on cost and asked if having the statue made was money well spent, Gifme was very forthright saying, "There is a cost to honouring the dead and as a society, we have to acknowledge that and honour our debts". Other statements expressing similar sentiments in the same tone were not hard to find, and it was as if there was no monetary cost too high with regard to making appropriate and formal remembrance. "When you see it, you know what they had to do, and you know what we might have to do", was one other reaction, given more definite form by Veteran Major 3, who not only firmly agreed with that sentiment, but added that the statue was in its own way a clear statement of what he saw as the Black Watch ethos as displayed in every war: effective soldiering, struggle and sacrifice in the spirit of the Soldiers Prayer of St. Ignatius of Loyola. Nevertheless, there was at times an unspoken hint and one outright statement that, "while we remember the boys of yesterday, we will probably also have to remember the boys of today and tomorrow at some point".

Of course, the boys of today and tomorrow soon become the boys of yesterday who would be happy to admit that while their service was something of a formative experience, they would also say that being a retired or serving soldier is not some sort of a fixed state, either in a social, intellectual or occupational sense, for once out of uniform former serving soldiers who are then classed as retired seldom live the rest of their lives out of uniform as Corporal or Colonel (Retired). Political opinions and social attitudes acquired at some 
point during their lives can -and generally do- mediate their perceptions of the Great War as well as other conflicts. But where does that leave the "shared representation of the past" or the collective memory of those who took part in the discussions and interviews?

\section{Conclusion}

By way of a conclusion, the following description of the core collective memory of the Great War amongst serving and retired Black Watch soldiers derived from the results of the interviews as it stood at time of writing is offered.

Reduced to its essential components, it is a shared memory of sacrifice and loss, of duty, done in desperate circumstances in appalling conditions, and of decent men acting professionally as best they could. It is also a memory of acts of courage on battlefields where mistakes were made at all levels, and bitter lessons had to be learned, but retired and serving soldiers were very clear time and again that those who gave and executed the orders were 20th century men and should not be judged by 21 st century standards. This collective memory also has at its heart the idea of respect for those who served and fell and an omnipresent sense of indebtedness for their sacrifice.

It is also important to say what this core collective memory is not: neither raw triumphalism nor raw despair has any place here. It is not obsessed with blame, be that of officers or politicians or the enemy. Historiographical issues and debates around the ongoing rebalancing of popular understanding of the war by revisionist historians find no echo in the core collective memory almost certainly because, at the tip of the bayonet, higher command and political leadership have precious little meaning. The men at the front had an experience that simply reflected what was happening moment by moment, so inevitably, the core collective memory focussed on that and so has no room for reflections on the higher direction of the war.

Finally, it is very noticeable too that some controversial issues widely discussed in the media during the centenary commemoration, such as underage soldiers serving in the front line or execution of men by firing squad for military crimes such as desertion, were not raised. Neither was there mention of the weapons and other paraphernalia of the Great War, such as tanks, machine guns, gas, and barbed wire, which featured prominently in British television documentaries and newspapers. At first, these omissions may seem strange, but perhaps for veterans and serving soldiers, these were the basic facts of wartime life and the new weapons developments simply tools of the trade. 


\section{Bibliography}

" Clark, A. "Inheriting the past: Exploring historical consciousness across the generations". Historical Encounters: A journal of historical consciousness, historical cultures, and history education, vol. 1, no 1 (2014).

" Gillis, J. R. "Memory and Identity: The History of a Relationship". In Commemorations: The Politics of National Identity. Ed. by John R. Gillis. Princeton: Princeton University Press, 1994.

" Halbwachs, M. Les Cadres sociaux de la mémoire. Paris: Albin Michel, 1994.

" Heathorn, S. "The Mnemonic Turn in the Cultural Historiography of Britain's Great War". The Historical Journal, vol. 48, no 4 (2005).

" Kansteiner, W. "Finding Meaning in Memory: A Methodological Critique of Collective Memory Studies". History and Theory, vol. 41, no 2 (2002).

" Kendall, T. Poetry of the First World War: An Anthology. Oxford: Oxford University Press, 2013.

" Mccluskey, Tm. Black Watch Corner. Forfar: Twa Tams Publishing, 2016.

" Newbolt, Sir H. J. Poems: New and Old (English Poetry Second Edition). London: John Murray, 1921.

" Nora, P. “Between Memory and History". Representations, no 26 (1989).

" Rüsen, J. "Tradition: A principle of sense-generation and its logic and effect in cultural history". History and Theory, vol. 51, no 4 (2012).

"Stallworthy, J. H. The Oxford Book of War Poetry. Oxford: Oxford University Press, 1984.

\section{About the author}

Norman Fraser Brown holds a PhD in History from the University of Dundee (United Kingdom), where he is Honorary Research Fellow. After serving in the famous Scottish infantry regiment The Black Watch, he graduated from Stirling University before embarking on a career in Secondary teaching in Scotland.

He has contributed to a number of publications on the Great War and in 2020 he co-edited and contributed to The Black Watch in the Great War: Rediscovered Histories from the Regimental Family, with Dr Derek Patrick.

His main research interests concern the Great War, and in particular the Scottish military return migration of 1914-1918, the mobilization of Scottish society in support of the British war effort, and the impact of that war on village and small-town life. 


\section{Sobre el autor}

Norman Fraser Brown es Doctor en Historia por la University of Dundee (Reino Unido), de la que es Investigador Honorario. Después de servir en el famoso regimiento de infantería escocés The Black Watch, se graduó en la Stirling University antes de emprender una carrera de enseñanza secundaria en Escocia.

Es autor de varias publicaciones sobre la Gran Guerra y en 2020 colaboró y coeditó junto al Dr. Derek Patrick, The Black Watch in the Great War: Rediscovered Histories from the Regimental Family.

Sus principales intereses de investigación se refieren a la Gran Guerra, en particular a la migración militar de retorno escocesa del período 19141918, la movilización de la sociedad escocesa en apoyo al esfuerzo bélico británico y el impacto de la guerra en la vida aldeana y rural. 